\title{
Bryophytes in Cibodas Botanical Garden: Diversity and Potential Uses
}

\author{
Ainun Nadhifah ${ }^{1 凶}$, Madinatul Khujjah ${ }^{2}$, Pantalea Edelweiss Vitara ${ }^{3}$, Ikhsan Noviady \\ DOI: http://dx.doi.org/10.15294/biosaintifika.v10i2.14433 \\ ${ }^{1}$ Cibodas Botanic Gardens, Lembaga Ilmu Pengetahuan Indonesia (LIPI), Indonesia \\ ${ }^{2}$ Department of Biology, Faculty of Mathematics and Natural Sciences, Universitas Brawijaya, Indonesia \\ ${ }^{3}$ Department of Biology, Faculty of Biology, Universitas Gadjah Mada, Indonesia
}

\section{History Article}

Received 22 May 2018

Approved 27 July 2018

Published 30 August 2018

\section{Keywords}

Bryophytes; Cibodas Botanical Garden; Medicinal plant

\begin{abstract}
Research on the diversity of bryophytes in Indonesia has been generally accomplished. However, the publication of potential uses of this tiny plant is very limited. Cibodas Botanical Garden (CBG) as a center for ex-situ plant conservation has potential climate conditions as a location of bryophytes growth. The study aims to collect bryophytes in CBG and to identify their potential uses. Purposive sampling method was used on various substrates (soil, rocks, trees). Some environmental parameters were also recorded, for instance, substrate type, temperature, and humidity. All of bryophytes collections were taken to the laboratory for the identification and saved in Cianjur Herbarium Hortus Botanicus Tjibodasensis (CHTJ). A literature study was conducted to determine the potential uses of identified bryophytes species. From 153 collection numbers recorded in CBG, there were 42 species which have potential use. In addition, there were 42 species that potentially to be used as a medicinal plant, ornamental plants, uses in agriculture and environmental services. This study provides the initial information about the potential uses of mosses, liverworts, and hornworts particularly in Indonesia. Furthermore, these prospective utilization encourage the innovative research in Indonesia, particularly on alternative natural resources.
\end{abstract}

\section{How to Cite}

Nadhifah, A., Khujjah, M., Vitara, P., \& Noviady, I. (2018). Bryophytes in Cibodas Botanical Garden: Diversity and Potential Uses. Biosaintifika: Journal of Biology \& Biology Education, 10(2), 455-463.

(C) 2018 Universitas Negeri Semarang
Correspondence Author:

J1 Kebun Raya Cibodas, Sindanglaya, Cipanas-Cianjur 43253, Jawa Barat

E-mail: ainun.nadhifah@lipi.go.id
p-ISSN 2085-191X

e-ISSN 2338-7610 


\section{INTRODUCTION}

Recent awareness towards biodiversity does not only focus on large exotic plants but also plants which resembles unimportant, should also have a specific concern to be investigated, studied, and protected. Bryophytes are microscopic plants that have the same morphological appearance if not observed carefully. These plants belong to cyptogams and they are separated from vascular plants because of lacking vascular tissues (Vanderpoorten \& Goffinet, 2009). Primitive bryophytes have thallose body, whereas these thallose in the higher bryophytes resembles a high-level plant with erect stems and surrounded by leaves (Glime, 2013). Morphologically, bryophytes have a root-like structure or rhizoid to absorb the water as well as to attach the plants to the substrate. These plants which live mostly in wet and humid habitat in the lowlands and highlands are often considered as pioneer plants. This is because bryophytes can grow in various substrates where the higher plants cannot grow. According to So (1995), bryophytes cover through the rocks, tree trunks, walls, bricks, sometimes forming the mats like a green carpet.

Bryophytes as pioneering plants create primary and secondary habitats after environmental damage, they assist the soil stabilization through open-field colonization, play an important role in the nutrient recycling process, biomass production, carbon fixation and serve as an indicator of air pollution (Saxena \& Harinder, 2004). Due to the globalization and the growth of human population, the supply of alternative natural resources has raised. Bryophytes, the second largest group in plant kingdom, have been studied in order to find the innovative properties for human being. Recent study reveals the secondary metabolites of bryophytes that commonly used in ethno pharmacology and as medical plants for treatment of some diseases. For instance, Spaghnum spp. are known as an eye medicine, leather and cotton substitute as well as plant media, while Marchantia group have anti-inflammatory, antibacterial, anti-helminthic, anti-arthritic, pesticide, antitumor, cancer preventive, anti-histaminic, hepatoprotective, hypocholesterolemic and antiinflammation activities (Krishnan \& Murugan, 2014). In addition, bryophytes also have economic importance as a source of fuel, horticulture, and oil absorption. Furthermore, plants which do not have vascular system also serve as a habitat for invertebrates and commonly used as ground cover and planting media for orchid and Nepenthes (Hallingbäck \& Hodgetts, 2000).
Cibodas Botanical Garden (CBG) has the main role as an ex-situ conservation institution especially for tropical highland plants originating from West Java and Sumatra. This area is located at the foot of Mount Gede and Mount Pangrango with an altitude of $1,275 \mathrm{~m}$ above sea level and has an average temperature of $20.06^{\circ} \mathrm{C}$, humidity of $80.82 \%$ and an average rainfall of 2,950 $\mathrm{mm}$ per year. These climatic conditions tend to be potential for bryophytes' growth. In order to conserve the Indonesian bryophytes, CBG built moss garden in 2006. CBG also has some herbarium collection of bryophytes from Mt Gede Pangrango, Mt Salak, Mt Geulis, Mt Slamet, Mt Jambi, Borneo, and Enggano Island (Damayanti, 2006; Nadhifah \& Surya, 2016). However, the diversity of bryophytes in CBG has not been well documented.

Although research on the diversity of bryophytes in Indonesia has been widely performed, the publication of potential uses of these plants is very limited. In this case, bryophytes are the prospective object to increase the economic growth because this plant group not only provides social demands but also has economic value due to their exotic appearance. It is important to identify the potential uses of bryophytes to advance the studies of alternative natural resources. The purpose of this study was to record the bryophytes diversity in CBG and to determine their potential uses. The advantage of this research is to provide initial information about the prospective utilization of mosses, liverworts, and hornworts particularly in Indonesia.

\section{METHODS}

\section{Study sites}

Study was conducted from August 2015 to February 2016 at Cibodas Botanical Garden (CBG), West Java, Indonesia.

\section{Bryophytes sampling}

Purposive sampling method was used on various substrates (soil, rocks, trees). Some environmental parameters were also recorded, including: substrate type, temperature, humidity. GPS coordinates were generally recorded in one region. All numbers of bryophyte collection were taken to the laboratory to be identified.

\section{Identification}

Bryophytes were identified by using respective literatures, such as Mosses of The Philippines (Bartram, 1939), A Handbook of Malesian Mosses Volume 1: Sphagnales to Dicranales (Eddy, 1988), A 
Handbook of Malesian Mosses Volume 2: Leucobryaceae to Buxbaumiaceae (Eddy, 1990), A Handbook of Malesian Mosses Volume 3: Splachnobryaceae to Leptostomataceae (Eddy, 1996), Guide to The Liverworts and Hornworts of Java (Gradstein, 2011), Mosses and Liverworts of Hongkong (So, 1995), A Taxonomic Revision of The Thuidiaceae (Musci) of Tropical Asia, The Western Pacific, and Hawaii (Touw, 2001) Liverworts and Hornworts of Rwanda (Fischer, 2013).

\section{Literature study}

The literature study was conducted to gain more information about the potential use of identified bryophytes. The main sources used were Glime (2013), Glime and Schenk (1997) as well as other related sources (Table 1).

\section{Data analysis}

The data were analyzed descriptively. The selected species were explained in detail.

\section{RESULTS AND DISCUSSION}

There were 153 collection numbers recorded. From 90 species of bryophytes that were found in CBG, there were 42 species that have potential uses (Table 1). There are some prospective utilization which have been classified, such as medicinal plant, ornamental plant, utilization in agriculture and environmental services.

In Indonesia, utilization of bryophytes is still uncommon. This is because of lack publication about bryophytes which have potential uses. Some publications have been showed the diversity of bryophytes in Indonesia. However, the ethnobotanical study of bryophytes in Indonesia is still rare. The bryophytes widely used as an ornamental plant, for instance, as an accessories of bonsai, aquaria (mosses in aquarium), terrarium, and other decoration. Some bryophytes families that can be utilized as ornamental plants include Pottiaceae, Bryaceae, Hypnaceae, Leucobryaceae, Dicranaceae, Hypnodendraceae, and Hookeriaceae.

Barbula javanica is a member of the Pottiaceae (Figure 1a), morphologically has a small size with $1 \mathrm{~cm}$ tall and green tufts (Nath et al., 2011) which is usually found in rock substrates. This moss resemble a pad that can be used as a ground cover of plants in pots. Bryum is the largest genera of the Bryaceae and the most difficult genera of mosses to be identified (Zolotov, 2000). There were 71 species of Bryum found in East Asia, South Asia, and Southeast Asia (Ochi, 1985). The species which commonly found in
CBG that can be utilized as an ornamental plant is Bryum billardieri (Figure 1b). This species has variable in vigour, forming olive green to brownish tufts or mats.

Hypnaceae has members which commonly resemble the carpet or mats and has been widely used as a decoration, either in bonsai plants, terrarium, or as accessories in the pots (Figure 1c). The other unique life forms which have the appearance of a tree (dendroid), can be found on Hypnodendron or palm moss (Figure 1d) and Hypopterygium (Figure 1e) or peacock moss. Those are the exotic moss genus (Hallingbäck \& Hodgetts, 2000).

Leucobryaceae has a uniquely white or pale gametophyte (Figure 1f). This is because of the leukocyte cells located in the middle of the leaf. For instance, Leucobryum aduncum and Leucobryum javense, which morphologically characterized by the "dicranoid" sporophyte and the thick tapered leaf shape, commonly found in tropical and subtropical forest areas, mostly on the substrates with low (acidic) $\mathrm{pH}$ (Vanderpoorten et al., 2003).

The other beautiful moss genera are $D i$ cranoloma and Campylopus, which included in Dicranaceae, grow in tufts or loose mats with erect, lanceolate, and falcate secund leaves. These mosses usually grow in moist acidic habitats (Figure $1 \mathrm{~g}, 1 \mathrm{~h}$ ).

Several studies have shown the potential use of bryophytes as a medicinal plant. Bryophytes have various types of secondary metabolites such as terpenoids, flavonoids, saccharides, lipids, and phenylpropanoids (Asakawa, 2007; Sabovljević et al., 2016). The liverworts have a greater potential to be used as a medicinal plant, because these group have oil body which contain secondary metabolites.

The use of bryophytes as a traditional medicine has also been widely practiced in several countries, such as China, Europe, India, and America. Nevertheless, in some other countries are still rare. This is due to the lack of biomass production in the certain region (Sabovljević et al., 2016). In Indonesia, research on the potential use of bryophytes as a medicinal plant is already exists, but there is no evidence to suggest that these plants have been utilized as a traditional medicine. Dumortiera hirsuta in CBG was found on soil substrate in the water areas such as rivers, waterfalls, and ponds. This liverwort has a thin with the dark green color thallus, flat margin, and papilla on the rhizoid. D. hirsuta produces secondary metabolites called Riccardin D which can inhibit the growth of tumor cells (Liu et al., 2012). 
Ainun Nadhifah, et al. / Biosaintifika 10 (2) (2018) 455-463

Table 1. Potential use of bryophytes in Cibodas Botanical Garden

\begin{tabular}{|c|c|c|c|}
\hline Species & Family & Potential use & Source \\
\hline Aerobryopsis longissima & Meteoriaceae & Phytoremediation & (Lee et al., 1977) \\
\hline Anthoceros punctatus & Anthocerotaceae & $\begin{array}{l}\text { Agriculture (mychor- } \\
\text { rhiza) }\end{array}$ & (Schüßler, 2000) \\
\hline Barbula javanica & Pottiaceae & $\begin{array}{l}\text { Decorative plant, medici- } \\
\text { nal plant (antimicrobial) }\end{array}$ & $\begin{array}{l}\text { (Schenk, 1997); (Singh et al., } \\
\text { 2007); (Vats \& Alam, 2013) }\end{array}$ \\
\hline Bazzania sp. & Lepidoziaceae & $\begin{array}{l}\text { Medicinal plant (antimi- } \\
\text { crobial) }\end{array}$ & (Alam et al., 2015) \\
\hline Brachymenium nepalense & Bryaceae & $\begin{array}{l}\text { Antimicrobial; medicinal } \\
\text { plant }\end{array}$ & $\begin{array}{l}\text { (Krishnan et al., 2014); } \\
\text { (Wankhede \& Manik, 2015) }\end{array}$ \\
\hline Bryum billardieri & Bryaceae & Decorative plant & (Schenk, 1997) \\
\hline Campylopus crispifolius & Dicranaceae & Decorative plant & (Schenk, 1997) \\
\hline Campylopus micholitzii & Dicranaceae & Decorative plant & (Schenk, 1997) \\
\hline Campylopus umbellatus & Dicranaceae & Decorative plant & (Schenk, 1997) \\
\hline Cyathodium foetidissimum & Targioniaceae & Fragrance; fixative plant & (Allen et al., 2017) \\
\hline Dicranoloma reflexum & Dicranaceae & $\begin{array}{l}\text { Decorative plant, medici- } \\
\text { nal plant }\end{array}$ & (Junairiah et al., 2016) \\
\hline Dumortiera hirsuta & Marchantiaceae & $\begin{array}{l}\text { Medicinal plant (anti- } \\
\text { tumor) }\end{array}$ & (Liu et al., 2012) \\
\hline Ectropothecium ichnotocladum & Hypnaceae & Decorative plant & (Schenk, 1997); (Glime, 2013) \\
\hline Fissidens crassinervis & Fissidentaceae & $\begin{array}{l}\text { Medicinal plant (antibac- } \\
\text { terial) }\end{array}$ & (Glime, 2013) \\
\hline Fissidens javanicus & Fissidentaceae & $\begin{array}{l}\text { Medicinal plant (antibac- } \\
\text { terial) }\end{array}$ & (Glime, 2013) \\
\hline Frullania sp. & Jubulaceae & $\begin{array}{l}\text { Medicinal plant (antibac- } \\
\text { terial, anti-cancer) }\end{array}$ & $\begin{array}{l}\text { (Glime, 2013); (Asakawa, } \\
\text { 2007) }\end{array}$ \\
\hline Heteroscyphus argutus & Geocalycaceae & $\begin{array}{l}\text { Medicinal plant (anti- } \\
\text { cancer) }\end{array}$ & (Lin et al., 2012) \\
\hline Hyophila involuta & Pottiaceae & $\begin{array}{l}\text { Medicinal plant (antibac- } \\
\text { terial); ecocity }\end{array}$ & $\begin{array}{l}\text { (Glime, 2013); (Singh et al., } \\
\text { 2016) }\end{array}$ \\
\hline Hypnodendron sp. & Hypnodendraceae & Decorative plant & $\begin{array}{l}\text { (Hallingbäck \& Hodgetts, } \\
\text { 2000) }\end{array}$ \\
\hline Hypopterygium ceylanicum & Hypopterygiaceae & Decorative plant & (Schenk, 1997) \\
\hline Hypopterygium tenellum & Hypopterygiaceae & Decorative plant & (Schenk, 1997) \\
\hline Isopterygium albescens & Hypnaceae & Medicinal plant & (Krishnan et al., 2014) \\
\hline Jungermannia sp. & Jungermanniaceae & Medicinal plant & (Alam et al., 2015) \\
\hline Leucobryum aduncum & Leucobryaceae & $\begin{array}{l}\text { Decorative plant, medici- } \\
\text { nal plant (antifungal) }\end{array}$ & $\begin{array}{l}\text { (Schenk, 1997); (Glime, 2013); } \\
\text { (Junairiah et al., 2017) }\end{array}$ \\
\hline Leucobryum javense & Leucobryaceae & Decorative plant & (Schenk, 1997); (Glime, 2013) \\
\hline Marchantia paleacea & Marchantiaceae & $\begin{array}{l}\text { Medicinal plant (anti- } \\
\text { cancer) }\end{array}$ & $\begin{array}{l}\text { (Banerjee \& Sen, 1979); (Fara- } \\
\text { mayuda et al., 2013) }\end{array}$ \\
\hline Marchantia polymorpha & Marchantiaceae & $\begin{array}{l}\text { Medicinal plant (anti- } \\
\text { plasmodial, stomachache) }\end{array}$ & $\begin{array}{l}\text { (Jensen et al., 2012); (Rao \& } \\
\text { Chatterjee, 2014) }\end{array}$ \\
\hline Mastigophora diclados & Lepicoleaceae & $\begin{array}{l}\text { Medicinal plant (antimi- } \\
\text { crobial) }\end{array}$ & (Komala et al., 2010) \\
\hline Meteorium miquelianum & Meteoriaceae & Nesting material & $\begin{array}{l}\text { (Hallingbäck \& Hodgetts, } \\
\text { 2000) }\end{array}$ \\
\hline Octoblepharum albidum & Calymperaceae & $\begin{array}{l}\text { Medicinal plant (antibac- } \\
\text { terial, diuretic), repellent }\end{array}$ & $\begin{array}{l}\text { (Vidal et al., 2012); (Krishnan } \\
\text { et al., 2014) }\end{array}$ \\
\hline Pallavicinia $s p$ & Pallaviciniaceae & $\begin{array}{l}\text { Medicinal plant (antibac- } \\
\text { terial) }\end{array}$ & (Glime, 2013) \\
\hline Philonotis hastate & Bartramiaceae & $\begin{array}{l}\text { Medicinal plant antimi- } \\
\text { crobial) }\end{array}$ & (Oyedapo et al., 2015)Duby \\
\hline Plagiochila $s p$. & Plagiochilaceae & Antifeedant & (Asakawa et al., 1980) \\
\hline
\end{tabular}


Ainun Nadhifah, et al. / Biosaintifika 10 (2) (2018) 455-463

\begin{tabular}{|c|c|c|c|}
\hline Plagiochila spathulifolia & Plagiochilaceae & $\begin{array}{l}\text { Medicinal plant (antimi- } \\
\text { crobial) }\end{array}$ & (Alam et al., 2015) \\
\hline Plagiomnium succulentum & Mniaceae & Agriculture & (Glime, 2013) \\
\hline Pogonatum cirratum & Polytrichaceae & $\begin{array}{l}\text { Medicinal plant (anti- } \\
\text { cancer) }\end{array}$ & (Karim et al., 2014) \\
\hline Pyrrhobryum spiniforme & Rhizogoniaceae & $\begin{array}{l}\text { Medicinal plant (fever, } \\
\text { bowel complaints) }\end{array}$ & (Krishnan et al., 2014) \\
\hline Racopilum schmidii & Rhacopilaceae & $\begin{array}{l}\text { Medicinal plant (antimi- } \\
\text { crobial) }\end{array}$ & (Oyesiku \& Caleb, 2015) \\
\hline Rhodobryum giganteum & Bryaceae & $\begin{array}{l}\text { Medicinal plants (liver } \\
\text { treatment, antipyretic, } \\
\text { diuretic, antihypertensive, } \\
\text { sores) }\end{array}$ & $\begin{array}{l}\text { (Glime, 2013); (Krishnan et } \\
\text { al., 2014) }\end{array}$ \\
\hline Riccia junghuhniana & Ricciaceae & $\begin{array}{l}\text { Medicinal plant (ring- } \\
\text { worm) }\end{array}$ & (Glime, 2013) \\
\hline Sphagnum gedeanum & Sphagnaceae & $\begin{array}{l}\text { Agriculture (growing } \\
\text { medium), mattress }\end{array}$ & (Hotson, 1921); (Smith, 1932) \\
\hline Trichocolea sp. & Trichocoleaceae & $\begin{array}{l}\text { Medicinal plant (anti- } \\
\text { fungal) }\end{array}$ & (Perry et al., 1996) \\
\hline
\end{tabular}

Marchantia polymorpha is the most popular liverwort because it can be found easily everywhere. This thalloid liverwort has porous thallus with purplish line on the dorsal (Gradstein, 2011). This species produces Marchantin A, the compound which can fight against the parasites. Jensen et al. (2012) reported that Marchantin A form Marchantia polymorpha inhibits the proliferation of the Plasmodium falciparum. Furthermore, according to Rao \& Chatterjee, (2014), the thallus of $M$. polymorpha can be used as a medicine in a liver disease, curing yellow (jaundice), and reducing inflammation. Additionally, a young archegoniophore can be used to treat boils and tuberculosis (TB). The other Marchantiaceae, Marchantia paleacea, in contrast to Marchantia polymorpha, the thallus of this species have no midrib. Faramayuda et al. (2013) reported that $M$. paleacea contains the flavonoid which potentially used as an anticancer.

Mastigophora diclados is the leafy liverworts that morphologically has a pinnate leaf and plane margin. M. diclados contains sesquiterpenoid herbertenediol and (-) - mastigophorene D - which has a higher antioxidant activity compared with vitamin C. Komala et al. (2010) reported that the herbertan in this species could fight against Bacillus subtilis (the cause of food poisoning) and Klebsiella pneumonia (the cause of pneumonia).

Octoblepharum albidum is the type of mosses belonging to the Leucobryaceae. The size of this moss is large enough $(3 \mathrm{~cm}$ high) and it grows epiphytically with a pale white cushion. $O$. albidum have been used as a diuretic in India (Krishnan et al., 2014).

Rhodobryum giganteum, the mosses with dendroid life forms, has chemical compounds in the form of hydroxynamic acid and dihydroxicumarine that reported to treat heart disease and can be used as antipyretics, diuretic, and antihypersensitivity drug (Asakawa, 2007). In India, this moss is used to cure the external wounds (Krishnan et al., 2014).

Aerobryopsis longissima, a member of Meteoriaceae, has a pale green or yellowish leaves and usually shiny. A. longissima can absorb chromium, one of the air pollutant. According to Lee et al. (1977), this moss was able to absorb up to $5000 \mu \mathrm{g} / \mathrm{g}$ of chromium through the rhizoid, although it is not mentioned the mechanism on how this species fight against metals which are highly toxic to other plants. Furthermore, A. longissima has the potential to be used as phytoremediation. Sphagnum is included in order Sphagnales. This genus is widely known as an ancient groups by the single, monogeneric family Sphagnaceae. It often appears in wide range altitudes from 1000 $\mathrm{m}$ to $3500 \mathrm{~m}$, forming dense tufts or chusions in bogs, on wet grounds, along streams, and beside waterfall (Bartram, 1939; Eddy, 1988). Besides from their unique characters, these bryophytes which locally known as peat moss have many advantages on farming. Sphagnum was usually used to substitute medium in growing plants. Currently, these mosses sold as dry peat moss used in growing Nepenthes, orchid propagation, particularly for Phalaenopsis species (Yen \& Chang, 2011; The Carnivorous Plant Society, 2018). In addition, Sphagnum moss has contribution to reduce the plastic because it can be used as the materials for manufacturing compostable plant pots. They also have important role to protect the seedling plants and the cellar root vegetables from spoiling, insects, and other potential negative impact of tran- 

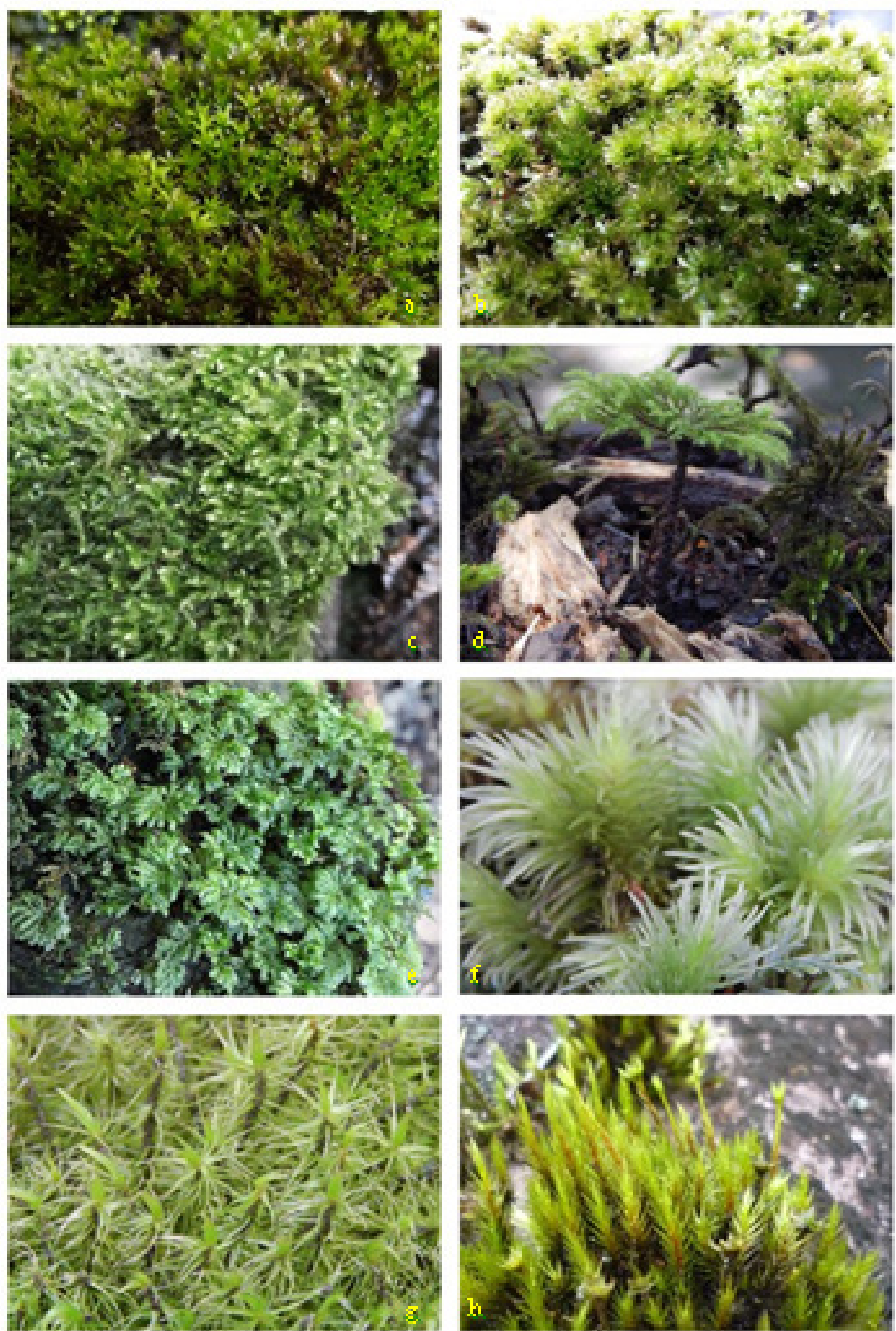

Figure 1. Some Bryophytes which potentially used as decorative plants: (a) Barbula javanica; (b) Bryum billardieri; (c) Ectropothecium sp., member of Hypnaceae; (d) Hypnodendron sp.; (e) Hypopterygium tenellum; (f) Leucobryum javense, member of Leucobryaceae; (g) Dicranoloma reflexum; (h) Campylopus umbellatus.

sporting materials (Pouliot et. al., 2015).

Marchantia and Sphagnum are the most genus which have been used by society in Indonesia. Biological compounds of Marchantia are widely studied, on the other hand, some farmer use Sphagnum or peat moss to increase their production. Although the application is still limited, the enormous of bryophytes' prospective uses encourage the advance research to develop the innovation from the alternative natural resources, specifically in Indonesia.

\section{CONCLUSION}

Cibodas Botanical Garden (CBG) as the center of ex-situ conservation for highland flora 
in Indonesia are also concerning in bryophyte conservation. The diversity of bryophytes in CBG are potentially used for ornamental plants, medicinal plants, agriculture and environmental services. These prospective utilization encourage the development of innovative study in Indonesia, particularly on alternative natural resources.

\section{ACKNOWLEDGEMENTS}

Authors thank to Winda Triana and Rifa'atul Mahmudah for technical assistance.

\section{REFERENCES}

Alam, A., Shrama, V., Rawat, K. K., \& Verma, P. K. (2015). Bryophytes - The Ignored Medicinal Plants. SMU Medical Journal, 2(1), 299-317.

Allen, N. S., Santana, A. I., Gómez, N., Chung, C., \& Gupta, M. P. (2017). Identification of volatile compounds from three species of Cyathodium (Marchantiophyta: Cyathodiaceae) and Leiosporoceros dussii (Anthocerotophyta: Leiosporocerotaceae) from Panama, and C. foetidissimum from Costa Rica. Boletín de La Sociedad Argentina de Botánica, 52(2), 357-370.

Asakawa, Y. (2007). Biologically active compounds from bryophytes. Pure and Applied Chemistry, 79(4), 557-580. https://doi.org/10.1351/ pac200779040557

Asakawa, Y., Yoyota, M., Takemoto, T., Kubo, I., \& Nakanishi, K. (1980). Insect antifeedant secoaromadendrane-type sesquiterpenes from Plagiochila species. Phytochemistry, 19, 2147-2154. https://doi.org/10.1016/S00319422(00)82212-8

Banerjee, R. D., \& Sen, S. P. (1979). Antibiotic Activity of Bryophytes. The Bryologist, 82(2), 141-153.

Bartram, E. B. (1939). Mosses of The Philippines. The Philippine Journal of Science, 68(1), 1-437.

Damayanti, L. (2006). Koleksi Bryophyta Taman Lumut Kebun Raya Cibodas Volume II No. 4. Jawa Barat: UPT Balai Konservasi Tumbuhan Kebun Raya Cibodas. Retrieved from https://krcibodas.lipi. go.id/sejarah.php

Eddy, A. (1988). A Handbook of Malesian Mosses (Sphagnales, Vol. 1). London: Natural History Museum Publications.

Eddy, A. (1990). Handbook of Malesian Mosses (Leucobryac, Vol. 2). London: Natural History Museum Publications.

Eddy, A. (1996). A Handbook of Malesian Mosses (Splachnobr, Vol. 3). London: Natural History Museum Publications.

Faramayuda, F., Ratnawati, J., Dewi, M. A., Adimurti, V., \& Syam, A. K. (2013). Isolasi Senyawa Sitotoksik Dari Lumut Hati ( Marchantia Paleacea Bertol .). In S. Meisyayati, M. Hasanah, A. A. Rasyad, A. Fatoni, L. Sirumapea, Lidia, ... Y. S. Wahyuni (Eds.), Prosiding Seminar Nasion- al Tumbuhan Obat Indonesia ke-44 (pp. 433-446). Palembang: Stifi Bhakti Pertiwi Palembang.

Fischer, E. (2013). Liverworts and Hornworts of Rwanda (Vol. 16). Brussels: Abc Taxa.

Glime, J. (2013). Uses. In Bryophyte Ecology (Vol. 5). Michigan: Michigan Technological University. Retrieved from www.bryoecol.mtu.edu

Gradstein, S. R. (2011). Guide to the Liverworts and Hornworts of Java (Prelim. ed). Bogor: SEAMEOBIOTROP.

Hallingbäck, T., \& Hodgetts, N. (2000). Mosses, liverworts and hornworts. Status Survey and Conservation Action Plan for Bryophytes. IUCN/SSC Bryophyte Specialist Group. IUCN, Gland, Switzerland and Cambridge, UK.

Hotson, J. W. (1921). Sphagnum Used as a Surgical Dressing in Germany during the World War. The Bryologist, 24(5), 74-78.

Jensen, S., Omarsdottir, S., Bwalya, A. G., Nielsen, M. A., Tasdemir, D., \& Olafsdottir, E. S. (2012). Marchantin A, a macrocyclic bisbibenzyl ether, isolated from the liverwort Marchantia polymorpha, inhibits protozoal growth in vitro. Phytomedicine, 19(13), 1191-1195. https://doi. org/10.1016/j.phymed.2012.07.011

Junairiah, Nurhariyati, T., Ni'matuzahroh, \& Sulistyorini, L. (2016). Isolation of bioactive compounds from Dicranaceae mosses. Journal Kimia Riset, 1(2), 111-121.

Junairiah, Nurhariyati, T., Zuraidassanaaz, N. I., Ni'matuzahroh, \& Sulistyorini, L. (2017). Antifungal Activity of the Some Mosses on Candida albicans. International Journal of Chem Tech Research, 10(1), 331-334.

Karim, F. A., Suleiman, M., Rahmat, A., Bakar, M. F. A., \& Bakar, M. F. A. (2014). Phytochemicals, Antioxidant and antiproliferative properties of five moss species from Sabah, Malaysia. International Journal of Pharmacy and Pharmaceutical Sciences, 6(10), 292-297.

Komala, I., Ito, T., Nagashima, F., Yagi, Y., \& Asakawa, Y. (2010). Cytotoxic, radical scavenging and antimicrobial activities of sesquiterpenoids from the Tahitian liverwort Mastigophora diclados (Brid.) Nees (Mastigophoraceae). Journal of Natural Medicines, 64, 417-422. https:// doi.org/10.1007/s11418-010-0423-8

Krishnan, R., \& Murugan, K. K. (2014). Comparison of GC-MS analysis of phytochemicals in the ethanolic extracts of Marchantia linearis Lehm \& Lindenb. and Marchantia polymorpha L. (Bryophyta). International Journal of Pharmaceutical Sciences \& Research, 5(5), 1981-1987. https://doi.org/10.13040/IJPSR.0975-8232.5(5).1981-87

Krishnan, V. G. M., Pradeep, D. P., Aswathy, J. M., Krishnan, R., Lubaina, A. S., \& Murugan, K. (2014). Wonder Herbals- Bryophytes, of the Ponmudi Hills, of Southern Western Ghats : Window Into the Need for conservation. World Journal of Pharmacy and Pharmaceutical Sciences, 3(4), 1548-1562. 
Lee, J., Brooks, R. R., \& Reeves, R. D. (1977). Chromium-Accumulating Bryophyte from New Caledonia. The Bryologist, 80(1), 203-205.

Lin, Z. M., Wang, L. N., Guo, D. X., Wang, X. N., Liu, Y. Q., Zhou, J. C., \& Lou, H. X. (2012). Secondary metabolites from the liverwort Heteroscyphus coalitus. Phytochemistry Letters, 5(3), 510-513. https://doi.org/10.1016/j.phytol.2012.05.002

Liu, H. P., Gao, Z. H., Cui, S. X., Sun, D. F., Wang, Y., Zhao, C. R., ... Qu, X. J. (2012). Inhibition of intestinal adenoma formation in APC Min/+ mice by riccardin $\mathrm{D}$, a natural product derived from liverwort plant dumortiera hirsuta. PLoS ONE, 7(3), e33243. https://doi.org/10.1371/ journal.pone. 0033243

Nadhifah, A., \& Surya, M. I. (2016). A Preliminary Study of Bryophytes in Enggano Island, Bengkulu, Indonesia. Biosaintifika: Journal of Biology \& Biology Education, 8(2), 201-205. https://doi. org/10.15294/biosaintifika.v8i2.5239

Nath, V., Asthana, A. K., \& Gupta, R. (2011). An overview of family Pottiaceae (Bryopsida) in central India with special reference to Pachmarhi Biosphere Reserve (PBR). Lindbergia, 34(January), 30-39.

Ochi, H. (1985). An annotated list of mosses of the subfamily Bryoïdeae in South, Southeast and East Asia.

Oyedapo, O., Makinde, A., Ilesanmi, G., Abimbola, E., Akinwunmi, K., \& Akinpelu, B. (2015). Biological activities (anti-inflammatory and antioxidant) of fractions and methanolic extract of Philonotis hastate (Duby Wijk \& MargaDant). African Journal of Traditional, Complementary and Alternative Medicines, 12(4), 50-55. https://doi. org/10.4314/ajtcam.v12i4.8

Oyesiku, O. O., \& Caleb, O. J. (2015). Antimicrobial Activity of Three Mosses, Calymperes Erosum Müll. Hal., Racopilum Africanum Mitt. , Cyclodictyon Mitt. From Southwest Nigeria. IOSR Journal of Pharmacy and Biological Sciences Ver. III, 10(2), 1-5. https://doi.org/10.9790/300810230105

Perry, N. B., Foster, L. M., May, B. C. H., \& Weavers, R. T. (1996). Isoprenyl Phenyl Ethers from Liverworts of the Genus Trichocolea: Cytotoxic Activity, Structural Corrections, and Synthesis. Journal of Natural Products, 59(8), 729-733. https://doi.org/10.1021/np9603378

Pouliot, R., Hugron, S., \& Rochefort, L. (2015). Sphagnum farming: A long-term study on producing peat moss biomass sustainably. Ecological Engineering, 74, 135-147. https://doi. org/10.1016/j.ecoleng.2014.10.007

Rao, G. M. N., \& Chatterjee, R. (2014). Folklore utilisation of bryophytes amongst the tribal regions of North Coastal Andhra. International Journal of Environment, 3(4), 101-108.

Sabovljević, M. S., Sabovljević, A. D., Ikram, N. K. K., Peramuna, A., Bae, H., \& Simonsen, H. T. (2016). Bryophytes - An emerging source for herbal remedies and chemical production. Plant Genetic Resources, 1-14. https://doi. org/10.1017/S1479262116000320

Saxena, D. K., \& Harinder. (2004). Uses of bryophytes. Resonance, 9(6), 56-65. https://doi. org/10.1007/BF02839221

Schenk, G. (1997). Moss gardening: including lichens, liverworts, and other miniatures. Portland, OR, United States: Timber Press.

Schüßler, A. (2000). Glomus claroideum forms an arbuscular mycorrhiza-like symbiosis with the hornwort Anthoceros punctatus. Mycorrhiza, 10, 15-21. https://doi.org/10.1007/ s005720050282

Singh, M., Rawat, A., \& Govindarajan, R. (2007). Antimicrobial activity of some Indian mosses. Fitoterapia, 78(2), 156-158.

Singh, V., Alam, A., \& Sharma, A. (2016). Evaluation of Phytochemicals, Antioxidant and Antibacterial Activity of Hyophila involuta ( Hook .) Jaeg . and Entodon plicatus C . Muell . ( Bryophyta ). International Journal of Scientific Research in Knowledge, 4(3), 56-63. https://doi. org/10.12983/ijsrk-2016-p0056-0063

Smith, H. H. (1932). Ethnobotany of the Ojibwe Indians. Bulletin of the Public Museum of the City of Milwaukee, 4(3), 327-525.

So, M. L. (1995). Mosses and liverworts of Hong Kong. Hong Kong: Heavenly People Depot.

The Carnivorous Plant Society. (2018). Nepenthes Tropical or Monkey Cup Pitcher Plant. Retrieved February 5, 2018, from http://www. thecps.org.uk/cms/fileman/upload/files/ Growing-Guides/Nepenthes.pdf

Touw, A. (2001). A Taxonomic Revision of The Thuidiaceae (Musci) of Tropical Asia, The Western Pacific, and Hawaii. J. Hattori Bot. Lab., 91, $1-136$.

Vanderpoorten, A., Boles, S., \& Shaw, A. J. (2003). Patterns of molecular and morphological variation in Leucobryum albidum, L. glaucum, and L. juniperoideum (Bryopsida). Systematic Botany, 28(4), 651-656. https://doi.org/10.1043/0247.1

Vanderpoorten, A., \& Goffinet, B. (2009). Introduction to Bryophytes. New York: Cambridge University Press.

Vats, S., \& Alam, A. (2013). Antioxidant activity of Barbula javanica Doz . et Molk .: A relatively unexplored Antioxidant activity of Barbula javanica Doz . et Molk .: A relatively unexplored bryophyte. Applied Botany, 65, 20103-20104.

Vidal, C. A. S., Sousa, E. O., Rodrigues, F. F. G., Campos, A. R., Lacerda, S. R., \& Costa, J. G. M. (2012). Phytochemical screening and synergistic interactions between aminoglycosides, selected antibiotics and extracts from the bryophyte Octoblepharum Albidum hedw (Calymperaceae). Archives of Biological Sciences, 64(2), 465-470. https://doi.org/10.2298/ ABS1202465V

Wankhede, T., \& Manik, S. (2015). Antimicrobial Po- 


\section{Ainun Nadhifah, et al. / Biosaintifika 10 (2) (2018) 455-463}

tential of the Moss Brachymenium turgidum Broth . ex . Dix . From Melghat Forest. International Journal of Life Sciences, 3(1), 63-66.

Yen, W. Y., \& Chang, Y. C. A. (2011). The acidification of sphagnum moss substrate during Phalaenop- sis cultivation. HortScience, 46(7), 1022-1026.

Zolotov, V. I. (2000). THE GENUS BRYUM ( BRYACEAE , MUSCI ) IN MIDDLE EUROPEAN RUSSIA. Arctoa, 9, 155-232. 